\title{
Comment on Francis van Loon, Stephane Delrue, and Wim van Wambeke, "Sociological Research on Litigation: Perspectives and Examples"
}

RUDI W. HOLZHAUER

Low Faculin, Erasmus University, Rostendam

ROB TEI

Senior Atrisor in Law and Economics, Duech Ministry of Justice

\begin{abstract}
The sociology of law has a long-standing tradition and indeed produced a vast literature in the area of litigation. Meanwhile, a complementary perspective has been presentod which we discuss with the following four perspectives: the relationship between legal cconomists and legal sociologists; the project of Van Loon, Delrue, and Van Whbeke; an overview of law and economics research with respect to the legal process; and the question of whether both approaches are complementary.
\end{abstract}

Keymonds: Litigation, legal process, economic v. sociological anslysis, empirical research

\section{The Relationship Between Legal Economists and Legal Sociologists}

It is noteworthy that the sociology of law has a greater variety of methodologies than has law and economics. With respect to its object of study, legal sociology also recognizes a wider range. For a long time it looked as if the role that legal sociology could have for legal policy making would be comparable to the role economic science could have for economic policy making. The question arises as to whether economics and sociology are different disciplines that provide complementary insights or whether one is a branch of the other. In our view both have their own autonomous spheres. Sometimes they provide complementary information regarding the law. Sometimes they pose different questions. The added value of sociology of law is not in discussion. The sociology of law provides insights where law and economics cannot. We will, however, vigorously object to claims that law and economics is not an independent way to obtain knowledge of legal phenomena. Hence, it is our firm belief that law and economics can provide insights where the sociology of the law in its turn cannot. These concern analyses that concentrate on efficiency and costs.

However, the relationship between law and economics and the sociology of law is not confined to a scientific discourse. In this respect we mention the often-heard but unjustified admiration for economics as an exact science. Surely, this is more of a psychological matter or a topic for sociology of science. For economists it is a matter of sound, healthy competition. 


\section{Comments on the Project of Van Loon, Delrue, and Van Wambeke}

The goal of the research project of Van Loon, Delrue, and Van Wambeke is to assess the significance of some perspectives of sociological research on litigation. Such a task is difficult to accomplish. Science seldom leads to definite and clear answers to practical questions. We probably all agree that the research subject of the social sciences, among which we explicitly count the science of economics, is complex and not easily reduced to simple theories or mechanisms. Unfortunately, difficult questions don't get answered by pointing out how difficult our scientific task is. One has to choose a method to deal with these social phenomena. Here our methods differ. Sociologists stress again and again the need to take into account the overwhelming diversity of social phenomena. In this respect the conclusion of the authors that not many grand sociological theories are used in litigation studies is not a surprise. Economists generally choose to work with simplyfing assumptions and proceed according the method of the so-called orderly loss of information.

Perhaps one can justifiedly criticize the law and economics movement for not having a long-standing tradition in empirical research. However, we would forcefully argue that it does provide a uniform framework not only for studying litigation topics but all areas of law. In this respect it does offer a grand theory, but one that recognizes its limits.

Van Loon, Delrue, and Van Wambeke distinguish two perspectives of analysis in the sociology of law, and their approach to sociology of law is bound to cause problems for legal economists. They refer to the scholar Van Houtte when they stress that "the characteristic frame of reference of sociology of law requires that all research should be based on some social problem or issue. This is a state of affairs in human relations that a certain group feels to be wrong and about which the need is felt to do something." Where Van Loon and colleagues put to us that the sociology of law needs the confrontation with a concrete question from social reality, we counterargue that for the economist the real world is often a special case! This is not to say that the issues are anything else than real problems. Economics, however, proceeds by developing models of social phenomena. By a model we mean a simplified representation of reality. The emphasis here is on the word simple. We do not look for an economic model (or any approach for that matter) that attempts to describe every aspect of reality. A model's power stems from the elimination of irrelevant detail, which allows the economist to focus on the essential features of the reality he or she is attempting to understand (Varian, 1993, pp. 1-2).

Quite another matter is the sociologists' inclination to take sides with the supressed or have-nots. It may appear that economists have fewer problems in analyzing situations from a given distribution of wealth and rights. Law and economics operates within the framework of critical rationalism and has as its ideal to eliminate value judgments as much as possible. Koen Raes (1990, blz. 385) is right in arguing that in positive law and economics value options cannot be avoided. Law and economics is value loaded. Objectivity as an ideal can only be achieved if the formal and material consistency of theories can be fully proven. However, hy potheses cannot be tested separately. Hence law and economics will have some subjective bias. It contains ideas-also paradigms (Kuhn) or hard core (Lakatos)-that are postulated and maintained for a long time without being falsified.

The study that Van Loon and Wouters have conducted into the quantitative relationship between the different stages of a conflict is interesting. It could be compared to the recent 
study of the Dutch National Bureau of Statistics. This latter shows how sensitive these outcomes are in relation to the type of conflict studied. The authors state that "Ultimately, only 11 percent of all conflicts were brought before the court. Little under half were settled informally; the remaining were given up at one stage or another." First, to us this seems a rather high percentage. A research project of the Oxford Centre for Socio-Legal Studies, aimed at different forms of legal protection for the financial consequences of illness and injury, found that less than one-half percent ever went as far as court (Harris, 1984). One course one should keep in mind that different types of cases will lead to differently formed pyramids (from baseline, the grievances, to top, the court filing), whereby (post)divorce cases end up in court much more frequently than tort or discrimination cases (Miller and Sarat, 1980-1981, pp. 525-566). Furthermore, legal cconomists are interested in the incentives parties have to opt for alternative ways of dispute resolution. Government provided courts represent only one method of resolving disputes. If they become too costly, disputants will turn to other forms: small claims tribunals, arbitration, out-of-court settlements, penalty clauses, and performance bonds. The court is in competition with these other techniques of dispute resolution, and the business will flow to the one that offers the best service at the lowest price. If alternative methods of dispute resolution are cheaper or faster, then not only will government-provided courts lose business, but government policy will focus on those less costly alternatives.

\section{Law and Economics Research}

Law and economics deals with economic explanations of the law and predictions of the consequences of legal rules. In order to explain these rules and their consequences the tools of microeconomic theory are used. The reason in that the rules created by law establish implicit prices for different kinds of behavior, and the consequences of those rules are analyzed as the response to those implicit prices (Cooter and Ulen, 1988, p. 11). It could be suggested broadly that the more important fields of law and economics research of litigation include a decision whether to settle or to go to trial, expenditures on litigation, and access to legal remedies (cost rules; contingent fees) (Ogus and Veljanovski, 1984, pp. 324-352). The field of litigation thus is a good example of an area of law where both disciplines are active.

Economists have analyzed civil procedure in the context of their perspective of law as a set of behavioral rules. This is partly captured by Posner's cost-effectiveness goal of minimizing the sum of direct and error costs. A more general model would also examine the impact of procedural rules on the incentives to avoid litigious matters. Two models can be distinguished (Scott, 1975, pp. $937 \mathrm{ff}$ ). The first is the conflict resolution model that sees civil process primarily as a method of achieving peaceful settlement of private disputes. This model, which underlies the way most lawyers view the courts, stresses such factors as the degree of harm, compensation, fairness, and minimizing the abuse of procedure by such practices as vexatious litigation, champerty, and maintenance. In contrast the behavior modification theory sees the courts' rulings as a way of altering behavior by imposing costs on a person. It focuses primarily on the behavior of defendants rather than the rights of plaintiffs, on whether the former, confront the appropriate set of costs and incentives, and the efficiency, consistency, and predictability of legal procedures. 
Error costs can take many forms. Statisticians frequently distinguish type I errors (failing to convict or penalize the guilty) from type II errors (convicting or penalizing the innocent). The significance of these errors will depend on the severity of the penalty. In a criminal case, where the accused cannot insure against the penalty and may be liable to imprisonment, a type II error will have serious consequences and is more likely to be avoided. This may explain why the standard of proof is higher in criminal cases than in civil cases. ${ }^{1}$

The majority of civil cases are settled out of court because it is cheaper. The economic model-first developed by Landes (1971) and discussed by Posner (see Gould, 1973; Friedmann, 1969)-suggests that litigation occurs because one or both parties are overly optimistic about their chances of winning. Litigation may also arise because the parties cannot agree on the sum that will settle the dispute (Cooter and Marks, 1982). In the economic analysis of litigation in this area the rationality assumption underlying economics can often found to be complemented with psychogical insights. Simon's bounded rationality stems from this element. In a Dutch study into lawyers' predictions of judicial decisions it was empirically shown that when predicting the outcome of their cases, lawyers first were sensitive to the factors that determine judicial decisions. This appeared from the fact that the success rate increased gradually along with their assessed probabilities. Second, however, a significant tendency toward overconfidence was found: lawyers generally estimated a too high probability of attaining their goals. This overconfidence was not extremely large, compared to overconfidence found for for example physicians (Malsch, 1989; ChristensenSalanszy and Bushyhead, 1981). If litigants behave as rational utility maximizers, then alternative methods of allocating legal costs will have predictable influence on their willingness to go to court (Shavell, 1982).

Some economists have questioned the social efficiency of the adversarial system. Thus Tullock $(1980$, ch. $6,1978,1971)$ has angued that it leads to excessive expenditure on litigation and that judges are undermotivated to seek out efficient solutions. It may also be socially inefficient to rely on the private financing of litigation. Precedents have public good qualities. A binding precedent not only decides the case but also influences the behavior and welfare of all potential litigants. Such legal rules may be underproduced since individual litigants will not take into account the total benefits:

The model has also been applied to investigate the impact of litigation on the development of precedent. Some (see Rubin, 1977; and Priest, 1977) have argued that the very existence of litigation encourages an evolution toward efficiency, since there is an incentive on the parties to settle claims based on efficient rules, but to challenge, and thus eventually to secure the correction of, inefficient rules. More recent work has indicated that this is only one of the many possible outcomes. The type of cases and their effects on substantive legal rules depend crucially on the assumptions regarding the behavior of the litigants and the judiciary (Carrington, 1979). The parties may be content with inefficient rules or be motivated to challenge efficient rules on distributional grounds (Kornhauser, 1980).

\section{Are Botb Disciplinary Appraaches Complementary?}

It is noteworthy that the subject of litigation has been extensively researched into by the two disciplines. Litigation proves to be a fruitful field for both. In 1988 both the economists 
Van Tulder and Janssen (1988) and the sociologist Klijn (1988) focused in their respective policy reviews on the price elasticity of the demand for legal services. Both were inspired by changes in Dutch law that make subsidized legal services more expensive. Both studies concluded that within the context of the present system the sensitivity of the demand for legal services is low.

In a comment on these two studies Griffiths wrote the following: "On the whole one can say that microeconomic analysis, insofar it has been applied to problems of choice, has not proven really revealing: neither the relevant variables nor their essential relationships to each other are different, for example in Klijn's more traditional sociological approach than in Van Tulder's and Janssen's approach. At most the microeconomic approach is a useful technique for data analysis, with a beguiling 'cleanness' which tends to make one overlook how many variables of well-established importance (e.g. culture and social structure) are being ignored, how many (often dubious) assumptions are being made, how weak the empirical base of the operation really is, etc. Still the proof of the pudding is in the eating. It will be interesting to see whether Van Tulder and Janssens' model is capable of accurately predicting future changes in the use and distribution of legal services" (Griffiths, 1989, p. 367). More recent studies have not falsified Janssen and Van Tulder's findings. However, in more recent work these authors have refined their analysis considerably. Thus they have split up the market for legal aid in partial markets to assess more accurately the effect of higher contributions has on different income groups (Van Tulder and Janssen, 1987-1989). Griffiths is right in underlining that microeconomic and welfare analysis can be seen as a set of tools. In our view, however, it is exactly this tool box that can be used eclecticly to deal with a wide variety of problems. With respect to the realism of assumptions we would answer it is not their reality but their usefulness we are concerned with. Some economists will argue that the realism of assumptions is totally irrelevant. Friedmann thus talks about "as if" explanations. If we observe an effect as a consequence of an individual's behavior, which should show if these individuals would behave in the way we assumed them to, then we are allowed to use these assumptions, even if they turn out to be incorrect. Therefore, it is not the behavior that is conform our assumptions, but the consequences of this behavior are presumed to correspond as if the individuals behave according to our assumptions.

In correspondence with our economic logic, recent research showed that the price elasticity for legal advice is higher than that for legal aid proper (aid in court proceedings) (Klijn, 1995). ${ }^{2}$ The fact that raising the amount litigants have to pay themselves results in a considerable reduction of legal advice work is in no way inconsistent with earlier findings. Price elasticity concerns changes at the margin. Hence one cannot extend such a finding to a situation where the changes in price are substantial.

It seems as if, on the whole, sociologists of law are not overenthusiatic about their new neighbor the economist. Some go even further: we observe that hard-core economic questions, such as the productivity of the courts and their optimal size, are considered to be nonscientific by some sociologists (letswaart, 1995). We do not find it very fruitful to draw a line between pure and applied science. Of course, on the whole a large number of economists are applying their trade. This does not make the purely scientific work less relevant in any way. One should keep in mind that the courts' capacity to handle cases certainly influences the access to justice. Furthermore, by taking into account that capacity in the process of law making, the legislator influences litigant options. 


\section{Notes}

1. On error costs see Posner (1973), and Tullock (1980). See further for over- and underinclusion Ehrlich and Posner (1974).

2. Report with first findings on the consequences of the revised Legal Aid Act with respect to the demand for financial legal aid.

\section{References}

Carrington, P.D. (1979). “Adjudication as a Private Good: A Comment." Joumal of Legal Studies \&, 303 ff. Christensen-Salanszy, J.J.J., and J.B. Bushybead. (1981). "Physicians" Use of Probabilistic Information in a Real Clinical Setting." Joumal of Experimental Pyychology: Human Perception and Performance 7, 928-935.

Cooter, R., and S. Marks. (1982). "Bargaining in the Stadow of the Lew: A Testable Model of Strategic Behaviour." Journal of Legal Studies 11, 225 ff.

Coover, R., and T. Ulen. (1988). Law and Economics. London: Scott, Foresman.

Ehrlich, I., and R.A. Posner. (1974). "An Economic Analysis of Logal Rulemaking." Joumal of Legal Studies 3, 257-280.

Friedmann, A. (1969). "The Anslysis of Setulement." Stanford Law Review 22, $67 \mathrm{ff}$.

Gould, J. (1973). "The Economists and Legal Conflices." Joumal of Legal Studies 2, $279 \mathrm{ff}$.

Griffiths, J. (1989). "Review." De Economist 137(3), 367 ff.

Harris, D. (1984). Compensation and Supporn for Illness and Injury. Oxford: Clarendon Press.

Ietswaart, H.F.P. (1995). "Over de sociale functies van rechlerlijke instanties [On the Social Functions of Courts]." Nederlands Juristenblad 70, 411.

Klijn, A. (1988). Duarder recht, minder vraag? [The Price-Elasticity of the Use of Legal Services]. WODC nr. 81. The Hague: Stantaruitgeverij.

Klijn, A. (1993). Met reche bijstand [Legal Aid Justified]. The Hague: SDU.

Kornhauser, L. (1980). "A Guide to the Perplexed Claims of Efficiency in the Law." Hofstra Law Review 8, 591 ff. Lendes, W.M. (1971). "An Economic Analysis of the Courts." Joumal of Law and Economics 14, $61 \mathrm{ff}$.

Malsch, M. (1989): Lonyers Predictions of Judicial Decisions: A Study on Calibration of Experts. Leiden: Leiden University.

Miller, R., and A. Sarat. (1980-1981). "Grievances, Chaims and Dispures: Assessing the Adversary Culture." Low and Society Review 15, 525-566.

Ogus, A.I., and C.G. Veljunowski. (1984). Readings in the Economics of Law and Regulation. Oxford: Clarendon Press.

Posner, R.A. (1973). "An Economic Approach to Lezal Procedure and Judicial Administration." Joumal of Legal Studies 2, $391 \mathrm{ff}$.

Priest, G.L. (1977). "The Common Law Process and the Selection of Efficient Rules." Joumal of Legal Strudies 6. 65 ff.

Raes, K. (1990). "Het recht van de schanste." Rechr en kritiek.

Rubin, P.H. (1977). "Why Is the Common Law Efficient?" Joumal of Legal Srudies 6, $51 \mathrm{ff}, 10,380 \mathrm{ff}$.

Scott, K.E. (1975). "Two Models of the Civil Process." Stanfond Law Review 28, $937 \mathrm{ff}$.

Shavell, S. (1982). "Suit, Settlement and Trial: A Theoretical Analysis Under Alternative Methods for the Allocation of Costs." Joumal of Legal Studies 11, $55 \mathrm{ff}$.

Tullock, G. (1980). Trials on Trial: The Pure Theory of Legal Procedure. New York: Columbia University Press. Tullock, G. (1978). "The Efficient Organization of Trials." Kytlos 28, $745 \mathrm{ff}$.

Tullock, G. (1971). "Public Decisions as Public Goods." Joumal of Political Economy 79, $912 \mathrm{ff}$.

Van Tulder, F.P., and S. Janssen. (1987-1989). De prijsgevoeligheid wan rechtshulp [Price-Elasticity for the Demand of Legal Aid]. Justitielle Verkenningen 13, $46 \mathrm{ff}$.

Van Tulder, F.P., and S. Janssen. (1988). De prijs van de weg naar het recht [The Influence of Price on the Use of Legal Services]. Stukwerk nr. 45. Rijswijk: Sociaal en Cultureel planbureau.

Varian, H.R. (1993). Intermediate Microeconomics (3nd ed.). New York: W.W. Morton and Company. 